\title{
GREYWATER TREATMENT SYSTEM IN UNIVERSITI KEBANGSAAN MALAYSIA MOSQUE: UTILIZING FILTER WELLS AS AN ALTERNATIVE SUSTAINABLE INNOVATION
}

Nangkula Utaberta

Aisyah Nur Handryant

\author{
Universiti Putra Malaysia (UPM) \\ Serdang, Selangor, Malaysia \\ e-mail : nangkula_arch@yahoo.com \\ Architecture Department, Faculty of Engineering and \\ Built Environment. \\ Universiti Kebangsaan Malaysia \\ Bangi, Selangor Darul Ehsan, Malaysia \\ e-mail : aisyahsadja@yahoo.com
}

\begin{abstract}
Water is one of the natural resources that support entire creature's needs in earth. It was also a key element of sustainable living. The important of water is proved by fact that human body were consists of $80 \%$ water which makes daily water needs is definitely important. Same thing was happen on earth which also consists of $71 \%$ water. Unfortunately, nowadays qualities as well as quantities of water is getting poor caused many environmental decline. Those situation is feel quite irony, first is because in one side human are depending on water badly, and in another side, qualities and quantities water have been decreasing because of their own. This environmental issue, especially water was realized by Universiti Kebangsaan Malaysia (UKM) by starting to be a first pioneer in Green \& Sustainability Campus in Malaysia. Although UKM is located in water-rich country, still UKM try to commit to save environment as well as manage its environment aspect. The usage of water in UKM itself is categorized in high level. UKM have around 20.000 students and most of them are dwelling in campus. For big campus like this, UKM had one main Mosque which accommodates some daily worship of Moslem as the majority one. For activities like ablution, washing and bathing, UKM Mosque had produce quite big amount of grey water. Grey water itself is residual water that still fresh and can be recycled for some purposes such as landscape irrigation and cleaning service. One alternative method to treats the grey water is by the usage of filter wells. This paper is trying to analysis and proposes some design of grey water system in UKM mosque in order to save environment. With proper grey water treatment, UKM Mosque will contribute to save water and UKM's environment. This successful water treatment is also can be an alternative model to apply in another building.
\end{abstract}

Keywords: filter wells, greywater, UKM Mosque

\begin{abstract}
Abstrak
Air merupakan satu dari sumber daya alam yang mendukung seluruh kebutuhan makhluk hidup di bumi. Air juga merupakan elemen kunci dari kehidupan yang berkelanjutan. Pentingnya air dibuktikan oleh fakta bahwa tubuh manusia $80 \%$ terdiri dari air yang membuat kebutuhan harian air sangat penting. Hal yang sama terjadi di bumi yang juga terdiri dari 71\% air. Sayangnya, akhir-akhir ini kualitas dan kuantitas air semakin buruk yang disebabkan oleh banyaknya penurunan kualitas lingkungan. Situasi ini terasa ironis, yang pertama karena pada satu sisi manusia sangat tergantung pada air, dan di sisi yang lain, kualitas dan kuantitas air telah menurun dengan sendirinya. Isu lingkungan, terutama air disadari oleh Universiti Kebangsaan Malaysia (UKM) dengan mulai menjadi pelopor dalam Green \& Sustainability Campus di Malaysia. Meskipun UKM berada di negara yang kaya akan air, tetap saja UKM mencoba berkomitmen untuk menyelamatkan lingkungan serta mengendalikan aspek lingkungannya. Penggunaan air di UKM sendiri dikategorikan ke dalam level yang tinggi. UKM memiliki sekitar 20.000 mahasiswa dan kebanyakan dari mereka tinggal di kampus. Untuk kampus yang besar seperti ini, UKM memiliki satu masjid utama yang mengakomodasi ibadah umat muslim sehari-hari. Untuk aktivitas seperti pembersihan, mencuci, dan mandi, masjid UKM menghasilkan cukup banyak air kotor. Air kotor itu sendiri merupakan sisa air yang masih bersih dan bisa didaur ulang untuk beberapa tujuan seperti pengairan lansekap dan cleaning service. Satu metode alternatif untuk memperlakukan air kotor adalah dengan menggunakan sumur penyaring. Makalah ini mencoba menganalisis dan mnawarkan beberapa rancangan sistem air kotor di masjid UKM untuk menyelamatkan lingkungan. Dengan perlakuan sistem air kotor yang benar, masjid UKM akan memiliki kontribusi untuk menyelamatkan air dan lingkungan UKM. Perlakukan air yang berhasil juga bisa menjadi alternatif model untuk diaplikasikan di bangunan yang lain.
\end{abstract}

Kata kunci: sumur penyaringan, air kotor, masjid UKM 


\section{Introduction}

The declining of environmental quality that accompanied with environmental pollution and loss of natural of natural resources are brings critical issues today. These issues were not only occurring in developing countries, but also become big global issues that concerns of all countries in the world. Currently, the global warming issues become the main agenda of our everyday conversation that ultimately bring us to think and act more wisely in treat nature and environment. The availability of water in tropical countries like Malaysia and Indonesia actually are pretty good and adequate. However it will not be sustained indefinitely without any effort to maintain, protect and preserve.

As we know, to keep environment from all declining, sustainable development becomes important concept. Sustainable is development that meets current needs without compromising the ability of future generations to meet their own needs. Basically, concept of sustainable development includes several fields, namely a social sustainable, economic sustainable and environmental sustainable. Water is one of resource that supports the humans need and other creatures; it is also one of a key element of sustainable living ${ }^{1}$.

The important of water is proved that the human body is consists $80 \%$ of water which makes the daily water needs for human beings is definitely important. Same happen in earth. Earth also consist around $71 \%$ of water, unfortunately the qualities of water is getting poor nowadays because many environmental decline. Chemically water molecule has a simple formula $\mathrm{H}_{2} \mathrm{O}$. Pure water has a neutral nature and a universal solvent for most mineral ${ }^{2}$.

Improving of water quality for humans can be done by conducting a water management. This management is possible from simple one to another complex way depend on the water quality from its source. More and more lower the resources of water quality will makes more and more techniques required for treating it. The enhancement of the water quantity is second requirements after the quality ones ${ }^{3}$.

On the other hand, the effort to water conservation is one of the important ways to maintain and keep quality and quantity of water well. Conservation is an act to save water that falls to the ground and manage its timing flow. These efforts will save enough water in the dry season and avoids destructive flooding. Any treatment given to a plot of land will affect the water system on it and the places downstream. Conservation of soil and water are two things that are closely related, the various soil conservation is also a part of water conservation or vice versa. Another important of conservation water is by recycling the residual water; by it residual water can be reuse and also can minimize the usage of water. While the purpose of water conservation is as follows:

a. Increase the volume of groundwater, adds to the capacity of groundwater and surface water by storing water when excessive.

b. Increase the efficiency of water usage, using as little as possible for specific purposes.

c. Improve the quantity and quality of water as intended.

\section{Definition of Grey Water}

The residual water divide into two designations, the one is the grey water and the other ones is black water. While, drinking water or clean water is called white or fresh water. The naming of grey water obtained from its grey appearance, but still has a fresh nature, while the black water is a designation for wastewater. Grey water is water that has a lower quality than white water (fresh water) but has higher quality than black water (sewage) ${ }^{4}$, refer on Table 1.

Table 1. Type of Water and Possible Use

\begin{tabular}{|c|c|c|}
\hline Water & Source & Possible uses \\
\hline Fresh water & $\begin{array}{l}\text { Ground \& surface } \\
\text { water }\end{array}$ & $\begin{array}{l}\text { Drinking, } \\
\text { cooking, bathing }\end{array}$ \\
\hline Greywater & $\begin{array}{l}\text { Bathing, cloth } \\
\text { washing }\end{array}$ & $\begin{array}{l}\text { Toilet cleaning, } \\
\text { irrigation, floor } \\
\text { washing, } \\
\text { construction after } \\
\text { treatment }\end{array}$ \\
\hline Black water & Toilet, urinal & $\begin{array}{l}\text { No use in } \\
\text { majority of the } \\
\text { cases and } \\
\text { requires } \\
\text { extensive } \\
\text { treatment - } \\
\text { ECOSAN toilet } \\
\text { can be an option }\end{array}$ \\
\hline
\end{tabular}

Source: National Environmental Engineering Research Institute \& UNICEF, 2007

In the context of household, the grey water is residual water from bathing, washing clothes, washing dishes, includes ablution. Ablution activity in the mosque had result large amount of grey water. In Indonesia for example, a country which has more than 700,000 mosques with the majority is Muslim sure have produced greywater ${ }^{5}$. These amounts does not include grey water that produced by another activities except ablution. For Muslim countries like Indonesia, Malaysia or Middle East countries can be ascertained that ablution and mosque is one of big producer of grey water in the country. Grey water regulations vary from state to 
state and it is important to be aware of local state and council rules.

The benefit of a grey water treatment system is that it improves the quality of water, and in another side it can also be used for surface irrigation or diverted inside the house for flushing the toilet, and washing clothes. Grey water divided into two designations that are first grey water that free from chemicals likes from ablution and second is grey water that contains chemicals like from bathing or washing. Grey water which is containing of these chemicals can be categorized into inorganic waste. Another benefits of grey water treatment is also can reduce fresh water requirement at once reduces sewage generations.

\section{Water Waste Treatment}

The principle is waste water treatment is to separate the harmful and undesirable particles from water or the effort to turning them into utilized substance. There are three ways to treat water, which are (1) physically process, (2) chemically process and, and (3) biologically process.

Firstly, physically process is precipitate process of large suspended and or floating materials in water. Screening is one of an efficient and inexpensive way to it. Suspended material which is easily sediment can precipitate easily whit it then. Flotation process widely used to set aside floating materials like oils and fats in order not to interfere next process. While filtration process is usually performed to precede the absorption process, this way aims to set aside as much as suspended particle in water in order not to disrupt absorption process. Material that use in absorption process is activated carbon.

Secondly, chemically process aims to remove particles that are not easily to precipitated (colloidal), heavy metals, phosphorus compounds and toxic organic substances, by putting certain chemical are required. Allowances for these materials principally are takes through the changes of its material properties, that is from cannot be precipitated into can easily precipitated (flocculation-coagulation). Basically, chemically process has high efficiency but the cost for it is quite expensive because required chemical material.

Thirdly, biological process is a method that utilize microorganism as a catalyst to decompose the material contained in wastewater. This process is common way that choose among the physical and chemical ones because more effective, efficient and inexpensive. All biodegradable residual or waste water can process biologically. Basically, biological reactor process can divide into two types, (1) suspended growth reactor, and (2) attached growth reactor. In the suspended growth reactor, microorganism grows and develops in a state of suspension.

Reiterated treated wastewater in many forms, such as direct potable, indirect-potable, direct-nonpotable and indirect non-potable to overcome water scarcity (Figure 1). The technologies are available to make sewage portable; however, cost effectiveness will be a key parameter in deciding feasibility of wastewater treatment and reuse.

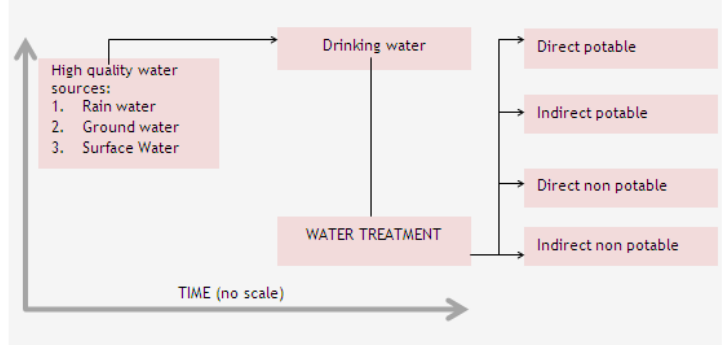

Figure 1. Wastewater as a Substitute for Higher Quality Water Resources

\section{Component of Greywater Treatment System} treatment

Primary treatment -pre-treatment to secondary

- Screening

- Equalization

Secondary treatment

- Gravel filtration

- Sand filtration

- Chlorination

Primary (pre-treatment) and secondary grey water treatment systems are useful in hostels, schools and residential complexes to treat grey water to the tune of $1000-2000 \mathrm{l} /$ day. A potential treatment scheme is shown in Figure 2.

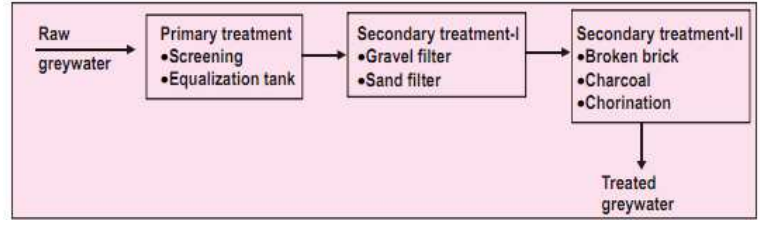

Figure 2. Grey water Treatment Scheme (primary \& secondary system). (Source: National Environmental

Engineering Research Institute \& UNICEF, 2007)

Another grey water treatment is by combine the three processes among physical, chemical and biological process. This treatment can perform likes as follows (Figure 3):

1. Precipitation process by putting alum

2. Screening (filtration) process by putting gravel, sand, broken bricks and or charcoal

3. The addition in final process with putting chlorine (calcium hypochlorite / $\mathrm{Ca}(\mathrm{OCL})_{2}$. 


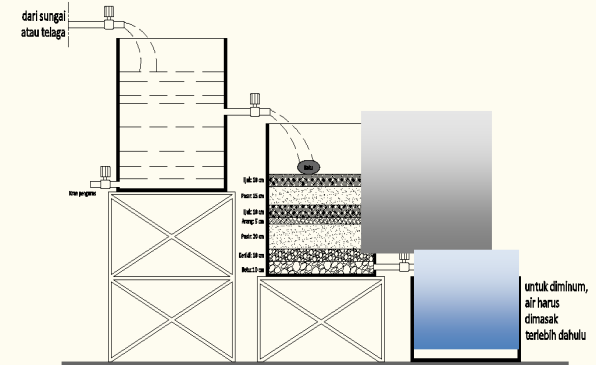

Figure 3. Greywater Treatment Scheme (combine system $)^{6}$

\section{Grey Water Treatment in Several Countries}

This part will explained the application of grey water treatment in several countries. The aim of this part is to know the several applications of grey water treatments which have done, to take some view and evaluation.

\section{a. Greywater treatment in Salman Mosque, ITB, Bandung, Indonesia}

Grey water treatment in Salman Mosque ITB start on 2003 organized by YPM Salman ITB through Empowerment Unit Research Institute (Salman Institute for Community Development) supported by Ministry of Research and Technorlogy through the program SIPTeMAN (Technology Incentive System and Management). First step is by doing several researches to obtain the inexpensive alternative technology to recycle ablution water. The research team consists of lecturer, students and practitioners. In an effort to spread the core technology is by woven into the community which cooperation with Al Falah Dago boarding school. The form of cooperation is by held entrepreneurship training with water recycling technology as a product and the engagement of students in research activities.

Basically, the principle of grey water treatment in this spot is by put grey water into some installation tank system. The working of this installation is ablution water will be accommodated in a tank then the water is put into the filtration and absorption tank. On filtration and absorption tank, ablution water and its impurities will be separated by filtration. The media which use is active sand. Impurities carried by ablution water will stuck in the sand while the water ablution will continue to flow into the next tank. Besides that, the pollutants contained in ablution water will will absorbed by the absorber that is used an activated carbon. Then, from the filtration tanks, the ablution water had poured into the chlorination tank. This is done so ablution water is free from harmful microorganisms. The process to removal harmful microorganisms is called disinfection, this process using chlorine. This step is held because there are some people who take the need for clean water and drinking water on taps of Salman Mosque. Water that has been in the disinfection will be accommodated in the final tank and then distributed through the water ablutions taps (Figure 4).

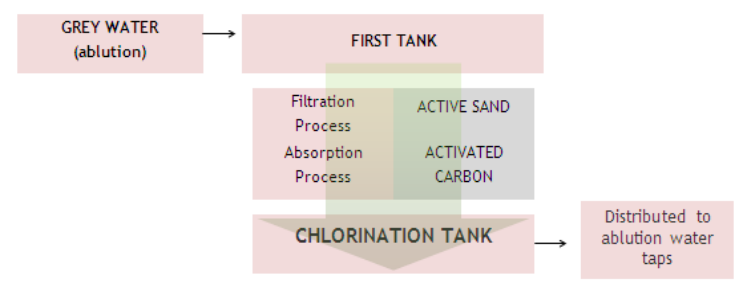

Figure 4. Greywater Treatment Scheme in Salman Mosque, ITB, Bandung Indonesia. (Source: Ilustration, 2011)

\section{b. Grey Water Treatment in Mohammed Hamoud Mosque in Al-Sib, Oman}

Researchers in Oman's Sultan Qaboos University (SQU) have designed a cost-effective system for recycling ablution water to be reused for irrigating the garden of a mosque. The filter, designed by an SQU Department of Soil, Water and Engineering research team, cost only $\$ 390$, which is far less expensive than imported grey water treatment units. The overall cost of the imported system was $\$ 3,900$. Engineer Sayf Al-Adawi, who was involved in devising the homemade filter, said that the annual maintenance costs do not exceed \$200 including scrapping off a $5 \mathrm{~cm}$ layer of the sand filter and replacement of enriched carbon.

Ablution water passes first through in filtration tank that is a sand layer for trapping solid matter, secondly passes the absorption tank through a layer of enriched carbon for deodorization. Water is then disinfected in final thank by passing through a chlorine pump. Treated water is gathered in a ground storage tank connected to a sprinkler irrigation system. This system is almost same with in Salman Mosque ITB, Bandung, Indonesia.

Grey water new treatment in Mohammed Hamoud Mosque in Al-Sib was dubbed "WWW", an acronym that stands for "Wudu' [ablution] Water Works". The service life of the filter was ten years. The system treats an average of around 1,000 liters of GW per day, with additional quantities on Fridays and during the month of Ramadan. Its maximum capacity is $4 \mathrm{~m}^{3}$, which is enough to meet any possible future increase in utilization. Grey water system which creates in Oman is an efficient and inexpensive system. These ways if used on a largescale in the Gulf States and other Islamic countries, will potentially lead to considerable water saving, in countries that are in arid and semi-arid belt and suffer from water scarcity.

From both examples of greywater treatment, which are in Salam Mosque, ITB, Bandung, Indonesia and Mohammed Hamoud Mosque in Al-Sib, Oman, known that basically grey water treatment divided 
into three processes. First is the filtration process by activated sand as its medium, second is the absorption process by activated carbon, and the last is The disinfected process in final thank by passing through a chlorine pump. The final process is to remove harmful material from water before distributing in tap of water before reuse.

\section{Result and Discussion}

\section{Introduction of UKM Mosque}

UKM Mosque is located in Universiti Kebangsaan Malaysia (The National University of Malaysia). The mosque is cultivated in $2 \mathrm{Ha}$ areas and located in front of the main entrance of university. This mosque has breadth of $25.713,41$ square meters (74.500 square feet) and accommodates around 5.000 peoples.

Based on research result noted that from 110 respondents, more than $40 \%$ indicated frequently go the mosque, and about $17 \%$ indicated very often go in it. From these findings, it may be noted that more than $50 \%$ of respondent were regularly coming to the mosque (Graphic 1).

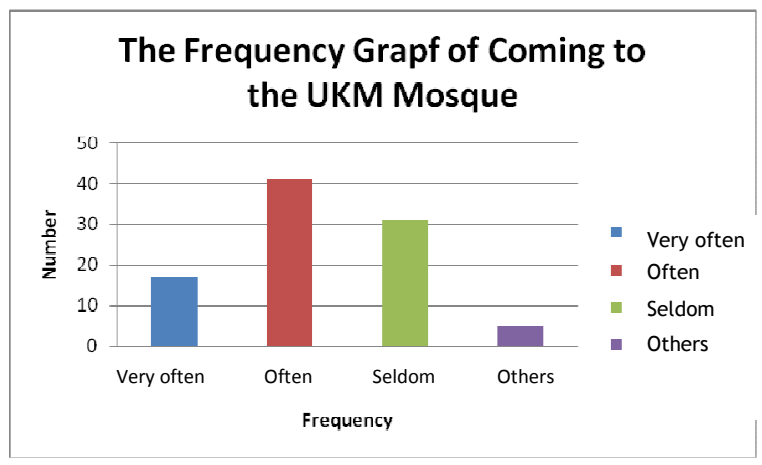

Graphic 1. The Frequency Graph of Coming to the UKM Mosque (Source: Observation, 2011)

UKM Mosque has some issues likes wastewater issue which quite common in many mosques, while in another side, the availability of water moreover limited in this world. Moreover, to know the level of waste water, researchers are also doing another research on naturalistic method.

This observation made to the water users in the UKM mosque, especially in ablution activity. The selection of naturalistic method is to know the real results on the behavior of waste water, because the respondents did not feel monitored and will performs as normal as usual. The result is known that the average of ablution water consumption is around 1,5 - 2 liter per person. Meanwhile, the most big number of visitors per day is in Zuhur and Ashar Prayer times, whereas in a week, the number of visitors is on Friday Prayer. Based on its observations, the act of waste water during ablutions due when visitors turn the water on with in great \& big flow and let the water run all the time for ablution even when not doing it. From these issues, the effort of grey water treatment in this mosque is quite urgent.

\section{Propose Design to Grey Water Treatment in UKM Mosque}

The design is proposed by the previous literature and precedent study. The grey water treatment will divide into three tanks which embedded in soil. Firstly grey water (ablution water) will be accommodated in first tank that is filtration tank. This filtration tank is filled by activated sand. Secondly, water will flow to second tank that is absorption tank. This second tank is filled by activated carbon to absorb the pollutant contained in ablution water. The last, grey water will flow to final thank that is the chlorination tank. This final step is done to make ablution water free from harmful microorganisms. The process to removal harmful microorganisms is called disinfection, this process using chlorine (Figure 5 ).

Grey water treatment installation system will completed with small covers in top of it to maintenance process. The mediums inside can replaced and added every time with open its cover (Figure 6).

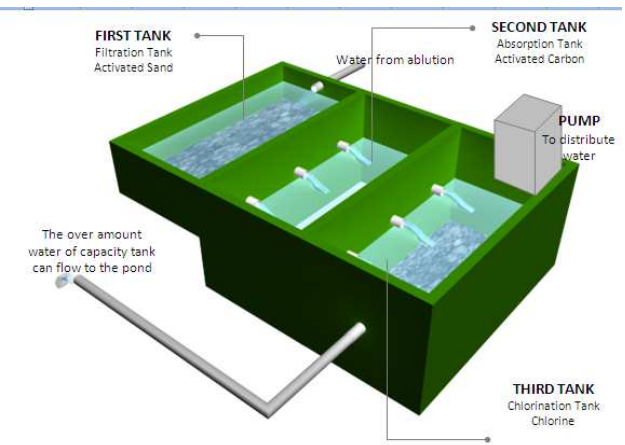

Figure 5. Propose Design of Grey water treatment in UKM Mosque

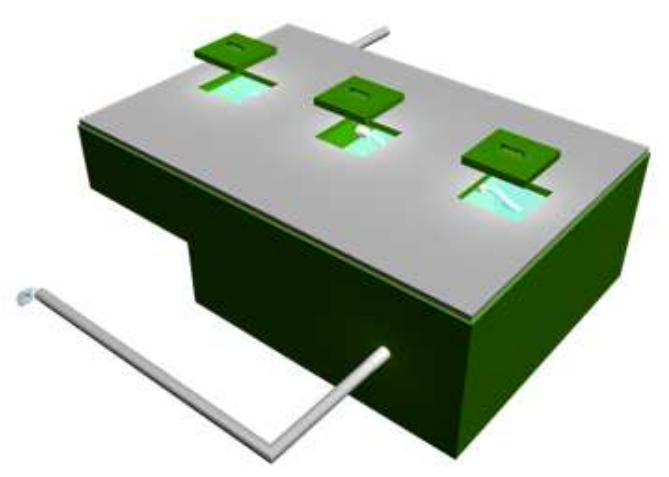

Figure 6. Small cover in each tank for maintenance process 


\section{Conclusion}

Grey water treatment is an effort to treat grey water into clean water so can reuse for other needs. The aim of this treatment is to minimalist the usage of fresh water for some need in UKM Mosque like fill pond, irrigation the landscape and flushing toilet. This effort is quite urgent in UKM because there is issue wastewater in UKM. The amount of grey water in this mosque is in high level. The grey water installation system is dividing into three steps. Firstly grey water (ablution water) will be accommodated in first tank that is filtration tank. This filtration tank is filled by activated sand. Secondly, water will flow to second tank that is absorption tank. This second tank is filled by activated carbon to absorb the pollutant contained in ablution water. The last, grey water will flow to final thank that is the chlorination tank. This final step is done to make ablution water free from harmful microorganism. For maintenance process, this installation completed with small cover that can open every time it needed.

\section{Reference}

1 Budi Wignyosukarto. 2008. Pengelolaan Sumberdaya Air Terpadu.

2 W. Stumm and J.J. Morgan. 1996. Aquatic Chemistry, Chemical Equilibria and Rates in Natural Waters. 3rd ed. John Wiley \& Sons, Inc., New York.

3 T.C. Sutrisno. 2004. Water Supply Technology. Jakarta: Rineka Cipta.

4 R. Jackson and E. Ord. 2000. Greywater reusebenefit or liability? The UK perspective. Water, 21, 38-40

5 Aisyah Nur Handryant. 2001. Mosque as a Community Development Center. Malang: UIN Press.

6 Tim Par. 2011. Participatory Action Research: Go Green. Malang: Laporan Pengabdian Masyarakat UIN Maliki Malang. 